\title{
Metabolic syndrome among elderly in a tertiary care center
}

\author{
Nagaraj S K ${ }^{1}$, Shashanka $\mathrm{K} \mathrm{S}^{2 *}$, Shashidhar $\mathrm{G}^{3}$, Vigneshwar $\mathrm{M}^{4}$ \\ ${ }^{1,2}$ Postgraduate, ${ }^{3}$ Professor, ${ }^{4}$ Assistant Professor, Department Of General Medicine, MVJ Medical College And Research Hospital, Bangalore, \\ Karnataka, India. \\ Email: shashankksrinivas@gmail.com
}

\section{$\underline{\text { Abstract }}$}

\begin{abstract}
Background: Metabolic syndrome (MS) is a premorbid condition with an inter-related cluster of metabolic abnormalities that involves glucose and lipid dysregulation, abdominal obesity and elevated blood pressure. It is estimated that 25 p.c of the world's population has MS. The geriatric population (aged $\geq 60$ years) is increasing rapidly in India, during the year 1991 it accounted for 6.7 p.c of the total population, rising to 7.4 p.c by the turn of the new millennium and is expected to increase to around 10.7 p.c by 2021 due to demographic transition. Aim and Objectives: To study the prevalence of metabolic syndrome and its risk factors among geriatric population. Material and Methods: A hospital-based, analytical cross-sectional study was conducted in the Department of General Medicine, MVJ Medical College and Research Hospital, Bangalore, Karnataka All the patients attending the General Medicine OPD aged 60 years and above who were willing to participate voluntarily were included. The study was conducted for a period of 6 months from $1^{\text {st }}$ October 2019 to $31^{\text {st }}$ March 2020. IEC approval and written consent were obtained. A detailed history was taken and examination done. A predesigned, pretested, semi-structured questionnaire was used to collect information regarding individuals' characteristics, personal habits, physical activity and harmful habits. Biochemical profile and anthropometric measurements were obtained. Data was analyzed in SPSS version-22 trial. Results: Prevalence of metabolic syndrome among the geriatric population was reported to be 44.7 p.c. Conclusion: Rapid changes in lifestyle, sociodemographic factors and disease transition in India, the metabolic syndrome prevalence found to be in an increasing trend.
\end{abstract}

Keywords: Elderly, Geriatric, Metabolic syndrome.

*Address for Correspondence:

Dr Shashanka K S, Postgraduate, Department Of General Medicine, MVJ Medical College And Research Hospital, Bangalore, Karnataka. INDIA.

Email: shashankksrinivas@gmail.com

Received Date: 06/11/2019 Revised Date: 13/01/2020 Accepted Date: 03/02/2020

DOI: https://doi.org/10.26611/10211518

This work is licensed under a Creative Commons Attribution-NonCommercial 4.0 International License.

\begin{tabular}{|l|l|}
\hline \multicolumn{2}{|c|}{ Access this article online } \\
\hline Quick Response Code: & Website: \\
\hline & www.medpulse.in \\
\hline
\end{tabular}

\section{INTRODUCTION}

Metabolic syndrome (MS) is a premorbid condition with an inter-related cluster of metabolic abnormalities that involves glucose and lipid dysregulation, abdominal obesity and elevated blood pressure. ${ }^{1}$ This premorbid condition develops due to insulin resistance and factors such as physical inactivity, obesity, poor diet and genetics. ${ }^{2}$ It may increase the risk of development various conditions such as type- 2 diabetes mellitus, coronary artery disease (CAD) and other cardiovascular diseases. ${ }^{3}$ Individuals with metabolic syndrome are at greater risk of cardiovascular mortality and morbidities. ${ }^{4}$ The geriatric population (aged $\geq 60$ years) is increasing rapidly in India, during the year 1991 it accounted for 6.7 p.c of the total population, rising to 7.4 p.c by the turn of the new millennium and is expected to increase to around 10.7 p.c by 2021 due to demographic transition. ${ }^{5}$ During the past decades, the prevalence of MS has markedly increased worldwide. ${ }^{6}$ It is estimated that 25 p.c of the world's population has MS. ${ }^{7}$ This estimate varies widely due to the age, ethnicity and gender of the population studied. ${ }^{8}$ About one third of the urban population in India has metabolic syndrome. ${ }^{9}$ As per International Diabetes Federation (IDF) 
- 2005 criteria the definition of metabolic syndrome was the presence of central obesity (waist circumference $\geq 90$ $\mathrm{cm}$ in men and $\geq 80 \mathrm{~cm}$ in women), plus $\geq 2$ of the following criteria: blood pressure $\geq 130 / 85 \mathrm{mmHg}$ or taking drug treatment for hypertension; serum triglyceride $\geq 150 \mathrm{mg} / \mathrm{dL}$ or taking specific treatment for this lipid abnormality; serum HDL cholesterol (HDLc) $<40 \mathrm{mg} / \mathrm{dL}$ in men and $<50 \mathrm{mg} / \mathrm{dL}$ in women, or taking specific treatment for this lipid abnormality; fasting blood glucose $\geq 100 \mathrm{mg} / \mathrm{dL}$, or previously diagnosed type 2 diabetes and taking specific drug treatment. ${ }^{10}$

\section{MATERIAL AND METHODS}

A hospital-based, analytical cross-sectional study was conducted in the Department of General Medicine, MVJ Medical College and Research Hospital, Bangalore, Karnataka. All the patients attending the General Medicine OPD aged 60 years and above who were willing to participate voluntarily were included. Patients who were severely ill, with cognitive difficulties and those who were not willing to fast over-night were excluded. The study was conducted for a period of 6 months from $1^{\text {st }}$ October 2019 to $31^{\text {st }}$ March 2020. IEC approval and written consent were obtained in prior. A detailed history was taken and examination done. A predesigned, pretested, semistructured questionnaire was used to collect information regarding individuals' characteristics, personal habits and harmful habits. Physical activity or performance status of the individuals was assessed by a modified ECOG ${ }^{11}$ (Eastern Cooperative Oncology Group) scale. Individuals' pattern of physical exercise was assessed by the total time spent every day walking and/or exercising, that may include pranayama or yoga or any other forms of exercise (for at least 30 minutes per day for a minimum of 5 days per week). Anthropometric measurements were obtained for every individual (height, weight, waist circumference) and BMI was calculated. Blood pressure was recorded for all the individuals who participated in the study. About 10 $\mathrm{mL}$ of blood was obtained from each individual after overnight fasting to estimate fasting blood glucose, serum triglyceride and high density lipo-protein (HDL) cholesterol. The data obtained was entered in Microsoft Excel and analyzed in SPSS version-22 trial. Appropriate statistical tests were used.

\section{RESULTS}

About 228 individuals who participated in the present study about 44.7 p.c (102) prevalence of metabolic syndrome was reported. Table-1 reports the sociodemographic factors of the study, majority 38 p.c (86) subjects were between $70-79$ years; majority 53.5 p.c (122) were males and 46.5 p.c (106) were females; majority 36.4 p.c (83) of the subjects were Hindu by religion; majority 66.7 p.c were literates and 33.3 p.c (76) were illiterates. Figure-1 reports that majority 66.7 p.c (152) were nonvegetarians and 33.3 p.c (76) were vegetarians; majority 73.7 p.c (168) of the subjects exercised less than 30 minutes a day and 26.3 p.c (60) of the subjects exercised $\geq 30$ minutes a day; majority 42.1 p.c (96) subjects reported physical activity ECOG grade-2; about 86.8 p.c (198) subjects did not have a harmful habit of smoking; about 94.7 p.c (216) subjects did not have a harmful habit of alcoholism. Body mass index (BMI) of the subjects was reported be less than $23 \mathrm{~kg} / \mathrm{m}^{2}$ in majority of the individuals 51.7 p.c (118) and $\geq 23 \mathrm{~kg} / \mathrm{m}^{2}$ among 48.3 p.c (110) subjects respectively. Table- 2 reports that the mean SBP among the subjects with metabolic syndrome was $145 \pm 7.3 \mathrm{~mm}$ of $\mathrm{Hg}$ and among the subjects without MS was $129 \pm 10.7 \mathrm{~mm}$ of $\mathrm{Hg}$; the mean DBP among the subjects with metabolic syndrome was $97.2 \pm 2.8 \mathrm{~mm}$ of $\mathrm{Hg}$ and among the subjects without MS was $87 \pm 4.8 \mathrm{~mm}$ of $\mathrm{Hg}$; the mean waist circumference among the subjects with metabolic syndrome was $92.6 \pm 1.8 \mathrm{cms}$ and among the subjects without MS was $77.3 \pm 6.7 \mathrm{cms}$; the mean BMI among the subjects with metabolic syndrome was $26.2 \pm 1.8 \mathrm{~kg} / \mathrm{m}^{2}$ and among the subjects without MS was $21 \pm 2.8 \mathrm{~kg} / \mathrm{m}^{2}$; the mean serum TG level among the subjects with metabolic syndrome was $156.4 \pm 11.2 \mathrm{mg} / \mathrm{dL}$ and among the subjects without MS was $122.4 \pm 8.7 \mathrm{mg} / \mathrm{dL}$; the mean serum HDL among the subjects with metabolic syndrome was $39.4 \pm 2.2 \mathrm{mg} / \mathrm{dL}$ and among the subjects without MS was $45.4 \pm 4.6 \mathrm{mg} / \mathrm{dL}$; the mean FBG among the subjects with metabolic syndrome was $115.6 \pm 9.9 \mathrm{mg} / \mathrm{dL}$ and among the subjects without MS was $73.6 \pm 4.4 \mathrm{mg} / \mathrm{dL}$ respectively. Table-3 reports MS among the individuals as per International Diabetes Federation (IDF) - 2005 criteria, the presence of central obesity (waist circumference $\geq 90 \mathrm{~cm}$ in men and $\geq 80 \mathrm{~cm}$ in women) among 91.1 p.c individuals; the presence of blood pressure $\geq 130 / 85 \mathrm{mmHg}$ or taking drug treatment for hypertension among 86.2 p.c individuals; the presence of serum triglyceride $\geq 150 \mathrm{mg} / \mathrm{dL}$ or taking specific treatment among 37.2 p.c individuals; the presence of serum HDL cholesterol (HDLc) $<40 \mathrm{mg} / \mathrm{dL}$ in men and $<50 \mathrm{mg} / \mathrm{dL}$ in women, or taking specific treatment among 38.2 p.c individuals; the presence of fasting blood glucose $\geq 100$ $\mathrm{mg} / \mathrm{dL}$, or previously diagnosed type 2 diabetes and taking specific drug treatment among 76.4 p.c individuals. 
Table 1: Sociodemographic Factors

\begin{tabular}{cccc}
\hline \multicolumn{2}{c}{ Socio-Demographic Factors } & Number of subjects ( $\mathbf{n}=228)$ & $\begin{array}{c}\text { Percentage of } \\
\text { subjects }\end{array}$ \\
\hline Age group, years & $60-69$ & 64 & $28 \%$ \\
& $70-79$ & 86 & $38 \%$ \\
Gender & $\geq 80$ & 78 & $34 \%$ \\
& Male & 122 & $53.5 \%$ \\
Religion & Female & 106 & $46.5 \%$ \\
& Hindu & 83 & $36.4 \%$ \\
Education & Christian & 76 & $33.3 \%$ \\
& Other & 69 & $30.3 \%$ \\
Previous occupation & Illiterate & 76 & $33.3 \%$ \\
& Literate & 152 & $66.7 \%$ \\
& Unemployed/housework & 42 & $18.4 \%$ \\
& Skilled worker & 34 & $14.9 \%$ \\
& Agriculture (land owner) & 42 & $18.4 \%$ \\
& Unskilled worker & 50 & $22 \%$ \\
& Service and business & 60 & $26.3 \%$ \\
\hline
\end{tabular}

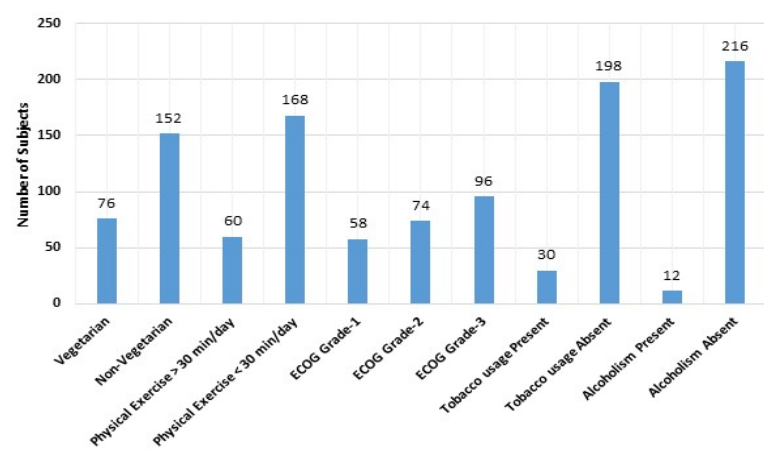

Figure 1: PERSONAL and HARMFUL FACTORS

Table 2: MEAN AND STANDARD DEVIATIONS OF VARIOUS PARAMETERS IN RELATION TO METABOLIC SYNDROME

\begin{tabular}{ccc}
\hline Parameter & \multicolumn{2}{c}{ Metabolic Syndrome [Mean (SD)] } \\
\cline { 2 - 3 } & Present $(\mathrm{n}=102)$ & Absent $(\mathrm{n}=126)$ \\
\hline Systolic blood pressure $(\mathrm{mmHg})$ & $145.0(7.3)$ & $129.0(10.7)$ \\
Diastolic blood pressure $(\mathrm{mmHg})$ & $97.2(2.8)$ & $87.0(4.8)$ \\
Waist circumference $(\mathrm{cm})$ & $92.6(1.8)$ & $77.3(6.7)$ \\
Body mass index $(\mathrm{kg} / \mathrm{m} 2)$ & $26.2(1.8)$ & $21.0(2.8)$ \\
Serum triglyceride $(\mathrm{mg} / \mathrm{dL})$ & $156.4(11.2)$ & $122.4(8.7)$ \\
Serum HDL cholesterol $(\mathrm{mg} / \mathrm{dL})$ & $39.4(2.2)$ & $45.4(4.6)$ \\
Fasting blood glucose $(\mathrm{mg} / \mathrm{dL})$ & $115.6(9.9)$ & $73.6(4.4)$ \\
\hline
\end{tabular}

Table 3: Components of metabolic syndrome

\begin{tabular}{|c|c|c|}
\hline Component of Metabolic Syndrome & $\begin{array}{l}\text { Number of subjects with } \\
\text { metabolic syndrome (\%) } \\
\text { [n=102] }\end{array}$ & $\begin{array}{l}\text { Number of subjects without } \\
\text { metabolic syndrome (\%) } \\
{[\mathrm{n}=126]}\end{array}$ \\
\hline $\begin{array}{c}\text { High blood pressure ( } \geq 130 / 85 \mathrm{mmHg} \text { ) or receiving drug treatment for } \\
\text { hypertension }\end{array}$ & $88(86.2)$ & $76(60.3)$ \\
\hline $\begin{array}{c}\text { Central obesity (waist circumference } \geq 90 \mathrm{~cm} \text { in men and } \geq 80 \mathrm{~cm} \text { in } \\
\text { women] }\end{array}$ & $93(91.1)$ & $35(27.8)$ \\
\hline $\begin{array}{c}\text { Raised serum triglycerides ( } \geq 150 \mathrm{mg} / \mathrm{dL} \text { ) or receiving specific drug } \\
\text { treatment }\end{array}$ & $38(37.2)$ & 15 (11.9) \\
\hline $\begin{array}{c}\text { Serum HDLc }<40 \mathrm{mg} / \mathrm{dL} \text { in men and }<50 \mathrm{mg} / \mathrm{dL} \text { in women or receiving } \\
\text { specific drug treatment }\end{array}$ & $39(38.2)$ & $12(9.5)$ \\
\hline $\begin{array}{c}\text { Fasting blood glucose } \geq 100 \mathrm{mg} / \mathrm{dL} \text { or previously diagnosed type } 2 \text { diabetes } \\
\text { receiving specific drug treatment }\end{array}$ & $78(76.4)$ & $31(24.6)$ \\
\hline
\end{tabular}




\section{DISCUSSION}

Among the elderly population of the present study, the overall prevalence of metabolic syndrome was reported to be 44.7 p.c, with a higher prevalence among women (55.4\%) than men (36.8\%). Pemminati S et al. ${ }^{12}$ in their study reported that the prevalence of metabolic syndrome was about 57 p.c with a higher prevalence of metabolic syndrome among females than males. Wasir JS et al. ${ }^{13}$ in their study reported that prevalence of metabolic syndrome was 40.2 p.c among the urban residents of Northern India. A study conducted in China reported that the prevalence of metabolic syndrome was 46.3 p.c among the elderly population. ${ }^{14} \mathrm{~A}$ high prevalence of metabolic syndrome among elderly women in the present study was probably due to the hormonal effects after menopause. Other Indian studies have reported a prevalence of metabolic syndrome ranging from 9.3 to 31.4 p.c respectively. ${ }^{15,16}$

\section{CONCLUSION}

Due to rapid changes in lifestyle, sociodemographic factors and disease transition in India, the metabolic syndrome prevalence found to be in an increasing trend. This high prevalence is a major concern to the country. There is need for an urgent attention of the health-care providers, policy makers and stake holders to take necessary actions.

\section{REFERENCES}

1. Huang PL. A comprehensive definition for metabolic syndrome. Disease models and mechanisms. 2009 May 1;2(56):231-7. (Last accessed on 06.05.2020).

2. Harikrishnan S, Sarma S, Sanjay G, Jeemon P, Krishnan MN, Venugopal K, Mohanan PP, Jeyaseelan L, Thankappan KR, Zachariah G. Prevalence of metabolic syndrome and its risk factors in Kerala, South India: Analysis of a community based cross-sectional study. PloS one. 2018;13(3). (Last accessed on 06.05.2020).

3. Wilson PW, D’Agostino RB, Parise H, Sullivan L, Meigs JB. Metabolic syndrome as a precursor of cardiovascular disease and type 2 diabetes mellitus. Circulation. 2005 Nov 15;112(20):3066-72. (Last accessed on 06.05.2020).

4. Klein BE, Klein R, Lee KE. Components of the metabolic syndrome and risk of cardiovascular disease and diabetes in beaver dam. Diabetes Care. 2002;25:1790-4. (Last accessed on 06.05.2020).
5. Central Statistics Office, Ministry of Statistics and Programme Implementation. Situation analysis of the elderly in India. June 2011. New Delhi: Government of India; 2011. Available from: http://mospi.nic.in/mospi_new/upload/elderly_in_india.pdf. (Last accessed on 06.05.2020).

6. Borch-Johnsen K. The metabolic syndrome in a global perspective. The public health impact--secondary publication. Dan Med Bull. 2007 May 2;54(2):157-9. (Last accessed on 06.05.2020).

7. O'Neill S, O'Driscoll L. Metabolic syndrome: a closer look at the growing epidemic and its associated pathologies. Obesity reviews. 2015 Jan;16(1):1-2. (Last accessed on 06.05.2020).

8. Kaur J. A comprehensive review on metabolic syndrome. Cardiology research and practice. 2014;2014. (Last accessed on 07.05.2020).

9. Kanjilal S, Shanker J, Rao VS, Khadrinarasimhaih NB, Mukherjee M, Iyengar SS et al.. Prevalence and component analysis of metabolic syndrome: an Indian atherosclerosis research study perspective. Vasc Health Risk Manag. 2008; 4:189-97. (Last accessed on 08.05.2020).

10. Recommended measurement protocols and derivations of indices. In: Physical status: the use and interpretation of anthropometry. Report of a WHO Expert Committee. Geneva: World Health Organization; 1995:424-38. Available from: http://apps.who.int/iris/bitstream/10665/37003/1/WHO_TRS 854.pdf. (Last accessed on 08.05.2020).

11. Lin WY, Huang HY, Lee SD, Liu CS, Lin CC, Huang KC. Metabolic syndrome of the elderly residents in long term care facilities. Taiwan Geriatr Gerontol. 2006;1(4):226-40. (Last accessed on 08.05.2020).

12. Pemminati S, Adhikari P, Pai MR, Pathak R. Metabolic syndrome among inmates of a 'home for aged' using IDF 2005 criteria. Nepal Med Coll J. 2009;11(1):31-3. (Last accessed on 09.05.2020).

13. Wasir JS, Misra A, Vikram NK, Pandey RM, Gupta R. Comparison of definitions of the metabolic syndrome in adult Asian Indians. J Assoc Physicians India. 2008; 56:158-64. (Last accessed on 09.05.2020).

14. He Y, Jiang B, Wang J, Feng K, Chang Q, Zhu S et al.. BMI versus the metabolic syndrome in relation to cardiovascular risk in elderly Chinese Individuals. Diabetes Care. 2007; 30:2128-34. (Last accessed on 09.05.2020).

15. Deepa R, Santhirani CS, Premalatha G, Sahtry NG, Mohan V. Prevalence of insulin resistance syndrome in a selected south Indian population - the Chennai urban population study-7 [CUPS-7]. Ind J Med Res. 2002;115:118-27. (Last accessed on 09.05.2020).

16. Kamble P, Deshmukh PR, Garg N. Metabolic syndrome in adult population of rural Wardha, central India. Indian $\mathrm{J}$ Med Res. 2010; 132:701-5. (Last accessed on 09.05.2020).

\section{Source of Support: None Declared Conflict of Interest: None Declared}

Policy for Articles with Open Access:

Authors who publish with MedPulse International Journal of Medicine, Print ISSN: 2550-7583, Online ISSN: 2636-4751 agree to the following terms: Authors retain copyright and grant the journal right of first publication with the work simultaneously licensed under a Creative Commons Attribution License that allows others to share the work with an acknowledgement of the work's authorship and initial publication in this journal.

Authors are permitted and encouraged to post links to their work online (e.g., in institutional repositories or on their website) prior to and during the submission process, as it can lead to productive exchanges, as well as earlier and greater citation of published work. 